\title{
La incidencia de la crisis económica en las instituciones administrativas
}

\author{
Antonio Marti del Moral \\ Profesor Titular de Derecho Administrativo. Universidad de Jaén \\ amarti@ujaen.es
}

Quería felicitar al Prof. Santiago Muñoz Machado por el éxito logrado en esta realidad que es el Seminario que reúne a profesores de toda España preocupados por la situación en la que se encuentran las instituciones públicas ante la crisis generalizada. En cuanto a mi intervención, quería destacar el acierto del Prof. Miguel Sánchez Morón en destacar la necesidad de asimilar en la política y en la sociedad las consecuencias derivadas del Derecho comunitario europeo y su incidencia en todo el ordenamiento nacional.

En efecto, como ha sido destacado en las ponencias aquí presentadas la "Constitución económica" no reside en el texto constitucional de 1978 sino en los Tratados de la Unión Europea que responden a unos principios concretos dirigidos a la creación de un mercado único y a la garantía de la libre competencia. Pienso que el debate doctrinal que se abre en torno a las ideas del Estado social y el mercado, entre la solidaridad y la libre competencia, se debe abordar teniendo como parámetro principal el derecho comunitario originario, más que el propio texto constitucional. Es en los Tratados donde se adoptan las decisiones políticas fundamentales que condicionan la actividad de los poderes públicos nacionales y los ciudadanos. Con este objetivo el debate científico sobre el Derecho ha de centrarse más a nivel europeo que en el estricto ámbito nacional pues las soluciones que no tengan una dimensión supranacional no serán viables fuera de nuestras fronteras en una economía globalizada. Por ello, me parece que en los debates políticos y sociales sobre la crisis económica resulta imprescindible poner de relieve las decisiones adoptadas en los Tratados de la Unión Europea y en los otros tratados que forman parte del derecho originario, pues gozan de una legitimidad propia, delimitan la acción de los poderes públicos y contienen los principios esenciales que explican las medidas adoptadas.

Pues bien, entre las decisiones básicas fundamentales ocupa un lugar primordial el principio de estabilidad presupuestaria tanto en el derecho comunitario europeo como en el derecho interno. De una parte, es preciso ponderar la relevancia del Pacto de Estabilidad y Crecimiento de 1997 como instrumento para lograr los objetivos de déficit público y deuda pública. Posteriormente, el Tratado de Lisboa profundiza en la adopción de medidas sobre la estabilidad presupuestaria en el artículo 126 (antiguo art. 104), el Protocolo sobre el procedimiento aplicable en caso de déficit excesivo y la Declaración núm. 30 del TFUE. De todo ello se ha dado cuenta en las intervenciones anteriores.

También en el ordenamiento nacional, la estabilidad presupuestaria, que había sido desarrollada en las Leyes de Estabilidad de 2001 y 2006, ha adquirido una nueva dimensión constitucional mediante la Ley de Reforma del art. 135 de la Constitución de 27 de septiembre de 2011. A partir de entonces, la estabilidad presupuestaria constituye "un valor verdaderamente estructural y condicionante del mantenimiento del Estado Social" según la Exposición de Motivos. Todo ello implica un cambio sustancial que afecta a la actuación de las Administraciones públicas y que todavía no ha sido suficientemente asimilado por la sociedad y los ciudadanos.

En definitiva, quería destacar la importancia de reflexionar y divulgar los motivos de fondo -especialmente, la estabilidad presupuestaria- , que se encuentran en los Tratados de la Unión Europea y han provocado las reformas constitucionales y legales en Europa, pues con ello se puede facilitar la comprensión en los planteamientos sociales, políticos y económicos sobre la crisis económica que atañen a los ciudadanos y la necesaria asunción de los efectos de estos cambios.

Termino con mi felicitación más sincera también a todos los Ponentes que han de forma coherente y atractiva los temas propuestos por la dirección del Seminario. Muchas gracias por su atención.. 